\title{
Assessment of Agricultural Water Use in Uzbekistan using Radiation Balance Method with Radiometric Data MODIS
}

\author{
Mukhamadkhan Khamidov, Javlonbek Ishchanov, Adham Mamataliev, Shavkat Botirov, \\ Akhrorkhon Khamidov
}

\begin{abstract}
The spatial images of agricultural water use in the irrigated lands of Khorezm region, located in the lower reaches of the Amudarya River, were mapped and monitored using the data from NASA's Moderate Resolution Imaging Spectroradiometer (MODIS). Land use categories at the case study areas were classified using a recursive partitioning and regression tree with $250 \mathrm{~m}$ MODIS NDVI time series. A seasonal existing evapotranspiration (ET) rate was obtained through application of the Surface Energy Balance Algorithm for Land to $1 \mathrm{~km}$ daily in MODIS data. In the Khorezm region, a seasonal maximum values for $E T$ was estimated at 1,000 and 1,200 $\mathrm{mm}$ for cotton and rice fields, respectively.
\end{abstract}

Keywords: MODIS, evapotranspiration, agricultural crops, heat balance of the earth, radiation, temperature, water use, and modeling.

\section{INTRODUCTION}

In the Amudarya downstream, most of the major water resources are used in agriculture, especially in farming. Soil moisture is essential for plant growth and development. The main agriculture includes cultivation of cotton and wheat [14], [15]. First, water contributes to the absorption of microelements in the soil, and if the soil is deficient in moisture, the growth of the plant declines and dies. Studies show that only about $0.03 \%$ of the water absorbed by the plant is spent on tissue formation and the rest is evaporated from the plant body (leaves, stems) [1].

Revised Manuscript Received on December 30, 2019.

* Correspondence Author

Mukhamadkhan Khamidov, Department of Irrigation and Melioration, Tashkent Institute of Irrigation and Agricultural Mechanization Engineers (TIIAME), Tashkent, Uzbekistan. Email: khamidov_m@mail.ru

Javlonbek Ishchanov*, Department of Irrigation and Melioration, Tashkent Institute of Irrigation and Agricultural Mechanization Engineers (TIIAME), Tashkent, Uzbekistan. Email: javlon@email.com

Adham Mamataliev, Department of Irrigation and Melioration, Tashkent Institute of Irrigation and Agricultural Mechanization Engineers (TIIAME), Tashkent, Uzbekistan. Email: mamataliev@inbox.ru

Shavkat Botirov, Department of Irrigation and Melioration, Tashkent Institute of Irrigation and Agricultural Mechanization Engineers (TIIAME), Tashkent, Uzbekistan. Email: batirov.sh@mail.ru

Akhrorkhon Khamidov, Department of Using hydropower and pump stations, Tashkent Institute of Irrigation and Agricultural Mechanization Engineers (TIIAME), Tashkent, Uzbekistan. Email ahmad.hamidov@gmail.com

(C) The Authors. Published by Blue Eyes Intelligence Engineering and Sciences Publication (BEIESP). This is an open access article under the CC-BY-NC-ND license http://creativecommons.org/licenses/by-nc-nd/4.0/
Water consumption of agricultural crops is determined by the amount of evaporation and transpiration from the soil, which is called evapotranspiration. Evapotranspiration of the geographic surface provides information about the state of plant water consumption, that is, the actual use of water.

As the Khorezm region is located in a arid region and the low amount of seasonal precipitation during the growing season requires artificial soil moisture. In recent years, the observed lack of water formed has led to serious consequences for agriculture [2]. In particular, the proper solution to the existing water resource allocation problem for water management organizations was the only way to maintain crop yields and achieve productivity. In these cases, it is important to learn how to use water across a geographic surface.

\section{MATERIALS AND METHODS}

Theoretical basis of Earth's heat balance

The equation of Earth's heat balance is related to the name Budiko [3]. Today, many studies related to the study of water consumption of plants have developed methods that take into account the heat balance of the earth [4], [5], [6], [7]. The thermal equilibrium of the earth is based on the solution of the heat balance equation, considering the essence of the heat exchange in the surface layer.

$$
\mathrm{R}=\mathrm{LE}+\mathrm{G}+\mathrm{H} \rightarrow \mathrm{LE}=\mathrm{R}-\mathrm{G}-\mathrm{H}
$$

Where: R-Radiation balance; LE- latent heat flux (E-evaporation, L- latent heat of evaporation); G- Soil heat flux; $\mathrm{H}$ - turbulent flow of air heat.

The radiation balance of the Earth consists in the arrival and return of solar radiation from the Earth, and the return of radiation from the atmosphere back to the Earth's surface. This process occurs in the form of different wavelengths of radiation (Figure 1).

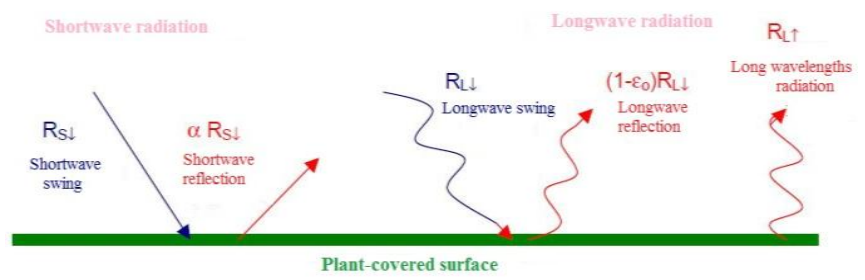

Figure 1. Radiation balance of the Earth's surface

Given the above, radiation equation can be described widely as follows. 


$$
\mathrm{R}=\mathrm{R}_{\mathrm{S} \downarrow}-\mathrm{R}_{\mathrm{S} \uparrow}-\mathrm{R}_{\mathrm{L} \uparrow}
$$

where: $\mathrm{R}_{\mathrm{S} \downarrow}$ - is incoming shortwave radiation (from 0,14 $\mu \mathrm{m}$ to $4 \mu \mathrm{m}) ; \mathrm{R}_{\mathrm{S} \uparrow}$ - is outgoing shortwave radiation; $\mathrm{R}_{\mathrm{L} \downarrow}$ - is incoming longwave radiation, (from $4 \mu \mathrm{m}$ ); $\mathrm{R}_{\mathrm{L} \uparrow}$ - is outgoing longwave radiation.

As it can be seen from the above formula, if the surface condition and atmospheric processes are not fully taken into account and the components were not accurate, the error will be huge. In many studies, earth radiation balance is expressed by other meteorological indicators as follows: [4], [8], [9], [10].

$$
R=(1-\alpha) \cdot R_{s \downarrow}+\varepsilon_{a} \cdot \sigma \cdot T_{a}^{4}-\varepsilon_{s} \cdot \sigma \cdot T_{s}^{4}
$$

where: $\sigma$-Stefan-Boltzmann constant $\left(5,67 \cdot 10^{-8}\right)$; $\alpha$-albedo; $\mathrm{T}_{\mathrm{a}}$ - air temperature; $\mathrm{T}_{\mathrm{s}}$-surface temperature; $\varepsilon$ - surface temperature distribution.

A part of the solar radiation that reaches the surface of the earth is converted into thermal energy, the process directly depends on the physical state of the earth surface where the sun rays. Pure snow-covered surface albedo up to $99 \%$ of the sun's rays, with only about $10 \%$ converting to heat. In the study work, the MOD13A2 (16-day NDVI) MODIS data type was used to calculate the above, the result of which showed high logarithmic regression.

\section{Modelling Evapotranspiration}

In the first stage, the evapotranspiration fraction is identified:

$$
E_{f}=\frac{L E}{R-G}=\frac{R-G-H}{R-G}
$$

where: $E_{\mathrm{f}}$ - evapotranspiration fraction.

At the next stage, the actual amount of evapotranspiration will be calculated based on agrometeorological indicators:

$$
\begin{aligned}
& E_{a}=E_{f} \cdot R_{\text {month }} \cdot 86400 \cdot 10000 \\
& \cdot\left[\left(2,501-\left(0,00236 \cdot T_{s}\right)\right) \cdot 10^{6}\right]
\end{aligned}
$$

where: $E_{a}$ - the amount of actual evapotranspiration; $R_{\text {month }}{ }^{-}$ monthly average solar radiation.

The amount of heat required to heat the soil is the ratio of the surface temperature to the albedo.

$$
\frac{L S T}{\alpha}
$$

where: LST-Land surface temperature.

In this case, MOD11 data is used to describe the surface temperature of $1 \mathrm{kmx} 1 \mathrm{~km}$ and the albedo MOD09 was used to calculate the amount of solar energy returning from the surface. For studying changes in plant cover used the information from Vegetation Index (MOD13 NDVI) and using the leaf area development index data (MOD15 LAI).

\section{Mapping Evapotranspiration}

When calculating and mapping evapotranspiration by using satellite imagery, it is assumed that there is a straight line top link between the vertical temperature gradient and the surface temperature. In Bastiaanssen [5], [11] and [12] researches the above correlation is well illustrated, suggesting that mapping the surface evapotranspiration is important to correctly identify two points, which are the driest pixels in the area and the wetest pixels without water surfaces.

$$
\begin{gathered}
\Pi_{\text {wet }}=R-G-k_{\text {wet }}(N D V I) \cdot L E T_{I V A N O V} \\
\Pi_{d r y}=R-G-k_{d r y}(N D V I, \text { Landuse }) \cdot L E T_{I V A N O V}
\end{gathered}
$$

Where: ET $_{\text {IVANOV }}$ - Monthly evaporation calculated by the evaporation formula of N.N.Ivanov.

\section{RESULTS AND DISCUSSION}

Land use map of Khorezm region provides information on the actual surface of 2017. According to Conrod [9], [13], in 2005, 59\% of Khorezm province was covered by agricultural crops. According to our research, in 2017 this indicator felled to $52 \%$.

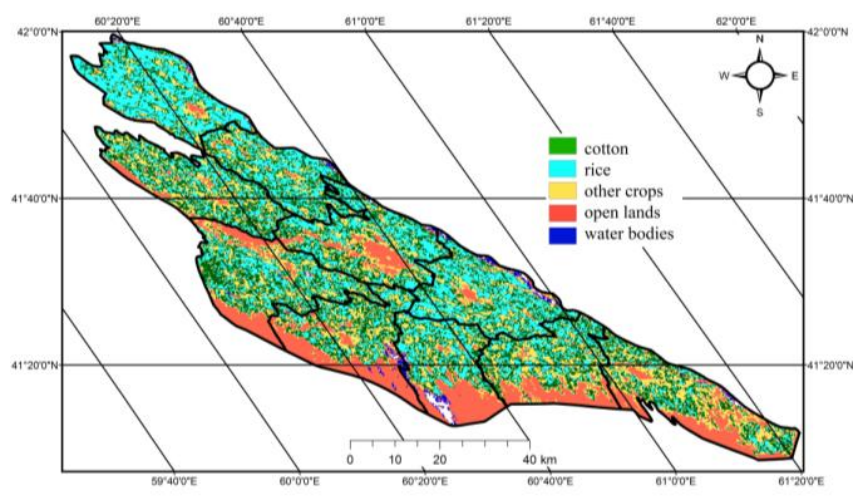

Figure 2. Land use map of Khorezm region in 2017

According to N.N.Ivanov's formula, the amount of evaporation at the beginning of the vegetation is $2.4 \mathrm{~mm}$ and the standard deviation is $0.72 \mathrm{~mm}$ (Fig. 3). The highest evaporation is observed in July and mean about $4.54 \mathrm{~mm}$ and the standard deviation is 0.31 . It is during this period that the plant's demand for water increases.

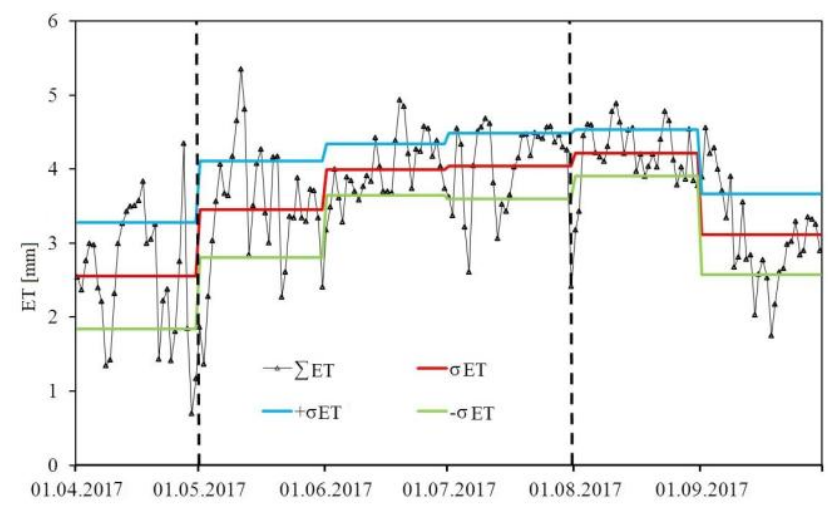

Figure 3. Amount of evaporation calculated by N.N.Ivanov's formula (Khiva meteorological station)

According to the evapotranspiration map $1450 \mathrm{~mm}$ water is evaporated from the open water bodies during the vegetation period. The lowest was found in sandy deserts with a maximum of $10 \mathrm{~mm}$ and high evaporation was observed in arable land near the Amudarya. High evapotranspiration was observed in the breadth of the Khorezm region, mainly in cropping areas on the left bank of the river. Evapotranspiration of cities was observed at 90-145 mm (Fig. 4). 
According to the results, surface efficiency in Khorezm region is high. The crop areas near the river have high yields and further water withdrawal from the river, the lower the water supply to the plant. This situation can also be seen on the surface earth class maps. The vegetation cover in the Khorezm region decreases as the river flows away from the river.

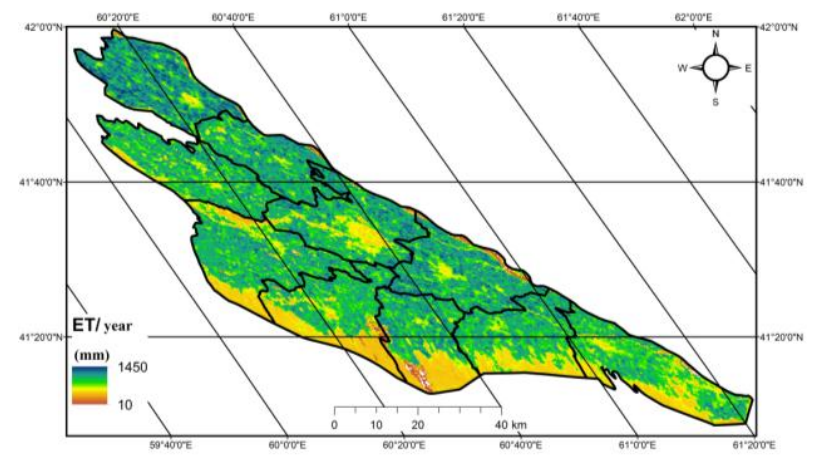

Figure 4. Geographic distribution of evapotranspiration during the 2017 growing season in Khorezm region

\section{CONCLUSION}

In this study, the spatial images of agricultural water use in the irrigated lands of Khorezm region, located in the lower reaches of the Amudarya River, were mapped and monitored using data from NASA's Moderate Resolution Imaging Spectroradiometer (MODIS). Land use categories at the case study areas were classified by using a recursive partitioning and regression tree with $250 \mathrm{~m}$ MODIS NDVI time series. According to the analysis, a seasonal existing ET rate was obtained through application of the Surface Energy Balance Algorithm for Land to $1 \mathrm{~km}$ daily in MODIS data. In the Khorezm region, a seasonal maximum values for ET was estimated at 1,200 and 1,000 mm for rice and cotton fields, respectively. To date, many studies in this area have been conducted, and the scope of its application remains largely within the natural sciences. Many of the environmental problems are utilized by using the Earth's energy and water balance models. Our research work contributes mainly for mapping the state of water use of geographic surfaces on a regional scale.

\section{REFERENCES}

1. I.D.Djumaniyazov and S.M.Kaziev, "Biological properties of irrigated soils under intensification". Tashkent, p 104, 1991.

2. A.Hamidov, J.Beltrao, A.Neves, V.Khaydarova, M.Khamidov. Apocynum Lancifolium and Chenopodium Album - potential species to remediate saline soils. WSEAS Transactions on Environment and Development, pp. 123-128, 2007.

3. M.I.Budiko, "Thermal balance of the earth's surface", Hydrometeorological publishing house. Leningrad p 256, 1956.

4. Ayoub Almhab and B.Ibrahim, "Estimation of Evapotranspiration Using Fused Remote Sensing Image Data and M-Sebal Model for Improving Water Management in Arid Mountainous Area", Int. Conf. on Water Resources and Arid Environments. Riyadh p 24, 2008.

5. W.Bastiaanssen, "Satellite surveillance of evaporative depletion across the Indus Basin", Journal of Water resources research. Washington p.1273, 2002.

6. J.R.Jensen, "Remote sensing of the environment: an earth resource perspective", New York, p 592, 2000.

7. W.Bastiaanssen, M.Menenti, R.A.Feddes and A.Holtslag, "Remote sensing surface energy balance algorithm for land (SEBAL)", Journal of Hydrology, New Zealand, p 198-212, 1998.

8. W.P.Kustas and J.M.Norman, "Evaluation of soil and vegetation heat flux predictions using a simple two-source model with radiometric temperatures for partial canopy cover", Journal of Agri. and Forest Met. New Haven, pp. 13-29, 1999.

9. C.Conrad, S.W.Dech, M.Hafeez, J.Lamers, Ch.Martius and G.Strunz, "Mapping and assessing water use in a Central Asian irrigation system by utilizing MODIS remote sensing products", Journal of Irrigation and Drainage Systems. Netherlands, pp. 197-218, 2007.

10. C.Conrad, S.W.Dech, M.Hafeez,J.Lamers, B.Tischbein, "Remote Sensing Based Hydrological Modeling for Irrigation Performance Assessment in the Lower Reaches of the Amu Darya River in Central Asia", Journal of Water Resources Management, Netherlands, pp.2467-2485, 2001.

11. W.Bastiaanssen, "SEBAL-based sensible and latent heat fluxes in the irrigated Gediz Basin”, Journal of Hydrology, Turkey pp.87-100, 2000.

12. K.Blumel, "A simple formula for estimation of the roughness length for heat transfer over partly vegetated surfaces", Journal of Applied Meteorology, Boston, pp.814-829, 1999.

13. C.Conrad, G.Ruecker, C.Schweitzer, S.Dech and M.Hafeez, "Modeling seasonal actual evapotranspiration with remote sensing and GIS in Khorezm region, Uzbekistan", Int. Symposium on Remote Sensing, Maspalomas pp. 214-224, 2004.

14. A.Hamidov, M.Khamidov, J.Beltrao, "Application of surface and groundwater to produce cotton in semi-arid Uzbekistan", The Asian and Australasian Journal of Plant Science and Biotechnology, pp. 67-71, 2013.

15. M.Khamidov, D.Nazaraliev, A.Hamidov, "Soil protection and anti-erosion techniques for cotton irrigation", International Journal of Geology, pp.17-19, 2009.

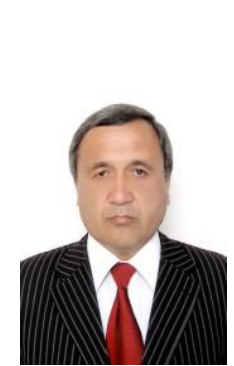

\section{AUTHORS PROFILE}

Prof. Mukhamadkhan Khamidov has been working at the Tashkent Institute of Irrigation and Agricultural Mechanization Engineers (TIIAME) in Uzbekistan since 1979. His background is hydraulic engineering. He received his $\mathrm{PhD}$ from the Uzbek Research Institute of Cotton Growing (SoyuzNIHI) in 1985 on "Irrigation regimes of cotton, alfalfa and maize on heavy loamy soils of the Khorezm oasis". Moreover, he successfully defended his doctoral dissertation in 1993 on "Scientific foundations for improving water use on the irrigated lands of the Khorezm oasis" and was awarded the academic title Professor. Prof. Khamidov worked as a Dean of Hydromelioration faculty at TIIAME during 1996-2010. He served as the director of Bukhara branch of TIIAME during 2010-2013. Last but not least, he was the Rector of TIIAME during 2013-2017. Since 2017 he works at the Department of Irrigation and Melioration at TIIAME, conducting research and lecturing the students on irrigation and drainage related studies. Under his direct supervision, more than $20 \mathrm{PhD}$ and Doctor of Sciences (DSc) students successfully defended their dissertations. Based on his scientific works, Prof. Khamidov has published more than 150 scientific works. More than 20 of his works have been published internationally (e.g. in the USA, Germany, Portugal, Austria, Greece, Russia, Ukraine, Kazakhstan and Moldova)

Noteworthy to mention that Prof. Khamidov was awarded the "Shukhrat" medal in the Republic of Uzbekistan and the honorary title of "Honored Worker of Science" in the Republic of Karakalpakistan for his active contributions to the field of agriculture and water resources. He was also awarded the Gold Medal in Science by the International Organization for Economic Cooperation and Development (OECD).

Currently, Prof. Khamidov is the chairman of the scientific seminar at the Specialized Council for awarding a PhD at TIIAME as well as a member of the Specialized Councils for awarding a DSc at TIIAME and SoyuzNIHI.

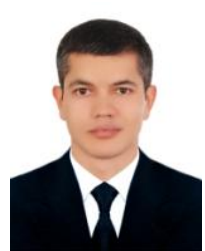

Javlonbek Ishchanov is an Assistant Professor as well as a PhD student at the Tashkent Institute of Irrigation and Agricultural Mechanization Engineers (TIIAME), Uzbekistan. He teaches Irrigation and Melioration course to undergraduate students. His background is water resources engineering. His research work is about the Impacts of Climate Change on Agricultural Water Resources. He has published more than 20 articles relevant to his research interests. 


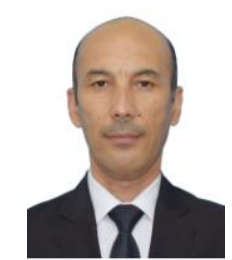

Adham Mamataliev is a full time docent (Associate professor) at the Tashkent Institute of Irrigation and Agricultural Mechanization Engineers, Tashkent, Uzbekistan. He teaches in the subjects of "Irrigation and Melioration", "Agricultural Hydrotechnical Melioration", "Land Recultivation", Modern Irrigation Technologies for 20 years. His research interest that Irrigation methods, Irrigation scheduling of agricultural crops, Salinity Problems in Irrigated area. He has published over 50 peer-reviewed papers in reputed international journals and conferences, besides 6 text-books and 1 monograph.

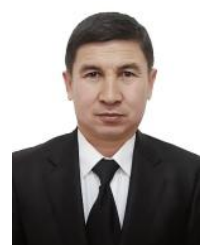

Shavkat Botirov is an Associate Professor at the Tashkent Institute of Irrigation and Agricultural Mechanization Engineers, Tashkent, Uzbekistan. He has defended his PhD in 2004. Dr. Shavkat Botirov teaching students in the subjects of "Irrigation and Melioration", "Modern Irrigation Technologies" and "Chemical melioration" for 15 years. He has published more than 40 peer-reviewed papers in international journals and conferences, two text-books and a monograph.

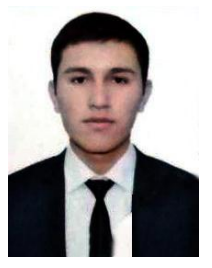

Akhrorkhon Khamidov has been a Master student since September 2019 at the Tashkent Institute of Irrigation and Agricultural Mechanization Engineers (TIIAME), Uzbekistan. He completed his undergraduate degree in July 2019 with honors in the Faculty of Hydropower and Pump Stations, TIIAME. He has participated in more than ten international conferences related to hydropower, pump stations, crop production, and water supply and conservation. During 26 August - 3 September 2017, A.Khamidov attended the Integrated Natural Resource Management course at Humboldt University of Berlin, Germany. He has published numerous articles nationally and internationally. 